Piotr Madajczyk

\title{
PRÓBY WZNOWIENIA PLANU RAPACKIEGO PRZEZ DYPLOMACJĘ POLSKĄ W PIERWSZEJ POŁOWIE LAT SZEŚĆDZIESIĄTYCH
}

Ramy ponownego podjęcia Planu Rapackiego stanowiła propozycja powszechnego i całkowitego rozbrojenia, zgłoszona przez ZSRS w 1959 roku. Do sowieckich inicjatyw stworzenia strefy bezatomowej w Europie Środkowo-Wschodniej oraz rozbrojenia w skali światowej nawiązywał już plan Rapackiego. Rozbieżne pozostają opinie, na ile był on własnym planem Ministerstwa Spraw Zagranicznych, a na ile narzędziem polityki sowieckiej. Skazani jesteśmy na domniemania, czy powstał w Moskwie czy też w Polsce, gdzieś między MSZ a KC PZPR. Czy Gomułka wykorzystał ambicje Rapackiego i czy polski minister spraw zagranicznych traktował nazwany jego nazwiskiem plan jako realny?

W ocenie MSZ kontrpropozycje amerykańskie zakładały rozbrojenie rozłożone na wiele lat i nie pozbawiały USA już w pierwszych jego etapach całego potencjału atomowego ${ }^{1}$. Dlatego w czerwcu 1960 roku polski wiceminister spraw zagranicznych, Marian Naszkowski, współdziałał zgodnie z polityką Moskwy w zerwaniu rokowań rozbrojeniowych NATO i Układu Warszawskiego (dalej UW) w Genewie ${ }^{2}$. W dniu 22

\footnotetext{
1 Aide-mémoire, luty 1961, Archiwum Ministerstwa Spraw Zagranicznych w Warszawie (dalej AMSZ) 26/3/22, s. 6-8.

2 J. Tebinka: Nadzieje i rozczarowania. Polityka Wielkiej Brytanii wobec Polski 1956-1970, Warszawa 2005, s. 135.
} 
września 1960 roku w ONZ został przedstawiony polski projekt Deklaracji o stworzeniu warunków sprzyjających osiagnięciu porozumienia w sprawie powszechnego i całkowitego rozbrojenia. W całościowym opracowaniu problemu rozbrojenia konwencjonalnego i broni masowej zagłady zaproponowano zaprzestanie prób z bronią jądrową zakaz przekazywania jej innym państwom oraz pomagania im $\mathrm{w}$ uruchamianiu jej produkcji. Przewidywano likwidację wyrzutni rakietowych. Na tej samej sesji ONZ Polska zaproponowała ogólnoświatowy plebiscyt, z pytaniem: Czy chcesz, żeby twój kraj posiadał broń atomową i wyrzutnie rakietowe ${ }^{3}$.

Jeżeli uwzględnić ówczesny kontekst międzynarodowy, to widać, że powyższe polskie propozycje rozbrojeniowe nie miały szans na realizację. Ich cel był przede wszystkim propagandowy, czyli służyły przedstawieniu krajów bloku sowieckiego jako obrońców pokoju. Tym samym wpisywały się w manipulowanie przez Moskwę obawami przed wybuchem konfliktu globalnego. $W$ ramach polityki sowieckiej propozycje te miały pomagać w prezentowaniu światowej opinii publicznej pokojowych dążeń państw bloku wschodniego. Niezależnie od tego, że stanowiły część globalnej polityki sowieckiej, miały także odpowiadać polskim interesom. Połączenie to $\mathrm{w}$ praktyce było trudne, gdyż osadzenie $\mathrm{w}$ planach sowieckich implikowało negatywne nastawienie państw zachodnich do polskich propozycji. Z perspektywy zachodniej oceniano, że nie zmniejszyłyby one zagrożenia, służyłyby zaś neutralizacji przyszłych zjednoczonych Niemiec ${ }^{4}$. Destabilizowałyby Europe, w której przewaga wojsk lądowych bloku wschodniego równoważona była strategią zmasowanego odwetu atomowego. Stabilizowałyby sowiecką strefę wpływów w Europie i służyły planom neutralizacji Niemiec, a nawet Europy, oraz ekspansywnym planom na kontynencie.

Niewątpliwie tkwiło w tym także polskie doświadczenie wojna, postrzeganie pokoju jako wyjątkowej wartości przez takich polityków, jak Adam Rapacki. Dochodziło do tego pragmatyczne przekonanie, że zbrojenia stanowią obciążenie gospodarcze dla systemu i utrudniają

3 T. Łoś-Nowak: Polskie inicjatywy w sprawie broni nuklearnej w Europie Środkowej 1957-1964, Warszawa 1989, s. 111-118.

4 M. Pasztor: Między Paryżem, Warszawa i Moskwa, Stosunki polsko-francuskie w latach 1954-1969, Toruń 2003, s. 164, ocenia go jako z góry pozbawiony szans. Uważa, że dyskusje o poprawkach służyły jedynie marginalizacji go na scenie publicznej. 
jego stabilizację; uniemożliwiają uzyskanie zaangażowania finansowego Zachodu i blokują transfer nowoczesnych technologii. Te rozważania można określić jako ogólne uwarunkowania, tworzące korzystne podłoże dla kontynuacji Planu Rapackiego.

Ponowne podjęcie Planu Rapackiego było m.in. odpowiedzią na integrację militarną następującą w ramach NATO. Polski MSZ ze szczególnym niepokojem śledził na początku lat sześćdziesiątych postępujące zbliżenie duńsko-niemieckie przy zabezpieczaniu cieśnin prowadzących na Bałtyk. Niepokoiła też integracja wojskowa, jak utworzenie wspólnego dowództwa RFN i Danii w rejonie Morza Bałtyckiego w 1961 roku. Polski dyplomata informował ambasadora Danii, J. Zytphen-Adelera: „w kroku tym widzimy wyraz dalszej ekspansji militaryzmu zachodnio-niemieckiego i rewizjonistycznych sił RFN; ekspansja ta skierowana jest na Wschód i na Morze Bałtyckie i niewątpliwie u podłoża jej, jeśli chodzi o plany militarystów zachodnio-niemieckich, są założenia agresywne" ${ }^{\prime \prime}$. W Warszawie z uwagą obserwowano rozbudowę przez RFN kooperacji z państwami zachodnimi w zakresie produkcji zbrojeniowej. Protestowano przeciw znoszeniu przez Unię Zachodnioeuropejską ograniczeń nałożonych na RFN w zakresie zbrojeń morskich. Co najważniejsze, w części kół rządowych USA (w tym prezydent Dwight D. Eisenhower) poparcie miała idea morskich sił zbrojnych, „Multilateral Force" (MFL), wyposażonych w broń jądrowa, podporządkowanych bezpośrednio dowództwu NATO i o wielonarodowym składzie. Dawałyby one państwom europejskim, także Niemcom Zachodnim, prawo współdecydowania o użyciu broni atomowej w razie ataku sowieckiego.

Według dyplomacji polskiej, polskie inicjatywy rozbrojeniowe miały chronić przed zagrożeniem niemieckim, zgodnie $\mathrm{z}$ tym, jak definiowano go w PRL, w tym przed uzbrojeniem RFN w broń atomową. Czytając dokumenty MSZ można dojść do wniosku, że blokowanie uzbrojenia RFN w broń atomową nie było dla polskiej dyplomacji celem najważniejszym. Eksponował to wyraźnie doradca ds. niemieckich, prof. Manfred Lachs, lecz nie wysuwały na plan pierwszy wyższe szczeble rzą-

5 Notatka Milnikiela z 13 grudnia 1961, AMSZ 26/1/9, s. 81. Polityka polska odpowiadała sowieckiej, w której starano się wywrzeć nacisk na Danię i uznawano wspólne dowództwo za przejaw działań antysowieckich i rosnących wpływów RFN. S. Stefański: Polityka zagraniczna Danii w latach 1945-1978, Warszawa 1979, s. 62. 
dowe. W polityce polskiej Plan Rapackiego był przede wszystkim narzędziem osłabiania międzynarodowej pozycji RFN, oskarżania Bonn o dążenie do konfliktu i eskalację zbrojeń.

W 1961 roku w MSZ uznano, że Plan Rapackiego, w zmodyfikowanej formie, może być nadal efektywnym narzędziem polityki, ,jako jeden z najlepszych środków ułatwiających drogę do powszechnego i całkowitego rozbrojenia". W notatce Lachsa i Mieczysława Łobodycza dla MSZ pisano:

„Zagadnieniem o centralnym znaczeniu dla rozwoju dalszej sytuacji w Europie, rzutującym w istotny sposób na całokształt stosunków między Wschodem a Zachodem, jest sprawa zbrojeń zachodnio-niemieckich, a zwłaszcza zbrojeń atomowych w NRF.

W związku z tym sprawa ta powinna być przedmiotem naszej nieustannej i stosownie do warunków w możliwie najbardziej skutecznej formie realizowanej akcji politycznej. Odnosi się to do każdej postaci zbrojenia atomowego NRF - bez względu na to, czy uchodzi o udostępnienie NRF broni atomowej, za pośrednictwem t.zw. atlantyckiej siły atomowej, czy też w jakikolwiek inny sposób.

W naszym interesie leży podkreślanie naszej gotowości do współdziałania $\mathrm{w}$ podejmowaniu kroków, które zapobiegałyby ryzykom związanym z zachodnio-niemieckimi zbrojeniami atomowymi, z umocnieniem pozycji politycznej NRF wobec państw zachodnich i możliwością wykorzystania przez NRF tej sytuacji. Możemy przy tym jednocześnie wykorzystywać i pogłębiać sprzeczności, zwłaszcza w krajach skandynawskich i w Anglii na tle sprawy zbrojeń atomowych w NRF. Zasadnicze znaczenie ma tu oddziaływanie na opinię publiczną $w$ tych krajach przy maksymalnym wykorzystaniu możliwości wpływania na pozycję niektórych kół rządowych w tych krajach. [...]

Koncentrując się na tych momentach moglibyśmy uzyskać mobilizację opinii publicznej na Zachodzie i zwiększenie oporów w różnych kołach burżuazji zachodnio-europejskiej (szczególnie skandynawskiej i angielskiej) oraz w samej NATO w stosunku do zachodnio-niemieckich zbrojeń atomowych. W konsekwencji mogłoby to opóźnić realizację planów uzbrojenia atomowego NRF. Osiągnięcie tego celu jest dla nas szczególnie ważne, gdyż wyposażenie NRF w broń atomową utrud- 
niłoby poważnie nasze wysiłki w kierunku wstrzymania procesu upowszechniania zbrojeń atomowych i faktycznej neutralizacji atomowej w Europie. Wpłynęłoby to zwłaszcza wybitnie niekorzystnie na sprawę neutralizacji atomowej w Skandynawii, a także na Bałkanach"6.

W cytowanej już notatce pisano: „moglibyśmy powiązać sprawę strefy bezatomowej w Europie środkowej z problemem Berlina Zachodniego. Koncepcję tę moglibyśmy skutecznie rozwijać, dochodząc w ostatecznym jej rozwinięciu do wysunięcia wniosku, że sprawa Berlina Zachodniego łączy się z problemem bezpieczeństwa zbiorowego w Europie i z uzbrojeniem Niemiec zachodnich". Wprawdzie przewidywano, że należy oczekiwać negatywnego stanowiska RFN, ale „Odrzucenie naszych propozycji przez NRF wzmocniłoby wobec opinii publicznej na Zachodzie nasze pozycje $\mathrm{w}$ sprawie Berlina Zachodniego. a także w sprawie traktatu pokojowego z Niemcami. W związku z tą sprawą możliwe jest również ujawnienie się sprzeczności między Kennedym i Adenauerem na tle ich stosunku do Berlina Zachodniego" ${ }^{7}$.

W tym układzie zmodyfikowana i poszerzona wersja Planu Rapackiego miała być prezentowana jako bezpośrednio przyczyniająca się do rozwiązania niektórych problemów politycznych. Szczególnie mogło to dotyczyć porozumienia w pewnych sprawach dotyczących Berlina Zachodniego, wychodząc naprzeciw obawom przed zaostrzeniem kryzysu wokół niego. Wymieniano w tym kontekście zobowiązanie do nieużycia siły, wyrzeczenie się działań prowadzących do eskalacji konfliktu, poszukiwanie środków sprzyjających pokojowemu współistnieniu w Europie Środkowej ${ }^{8}$.

Jednakże proponowane przez Lachsa i Łobodycza zmiany w Planie Rapackiego odnośnie do Berlina Zachodniego nasuwają wątpliwości, na ile poważnie rozważali oni możliwości jego realizacji. Proponowali bowiem, żeby poza zakazem rozlokowywania broni jądrowej i rakietowej ograniczenia dotyczyły zmniejszenia siły kontyngentów mocarstw zachodnich w Berlinie Zachodnim, zakazu wrogiej działalności propa-

${ }^{6}$ Niepodpisana notatka [1961], AMSZ 26/1/10, s. 17-24 i 52-61. Przygotowana została przez Lachsa z Łobodyczem na polecenie Rapackiego. W teczce zawarte są także kolejne jej wersje, niezmieniające jednak zasadniczych sformułowań. Cytat s. 52.

7 Ibidem, s. 53, 57.

8 Ibidem, s. 58. 
gandowej i dywersyjnej wobec NRD oraz, ewentualnie, zakazu poboru do Bundeswehry. Zagwarantowano by swobodę komunikacji i łączności Berlina Zachodniego z innymi krajami. Pomijano zaś sprawy komunikacji między Berlinem Wschodnim i Zachodnim ${ }^{9}$. Propozycje te nie były atrakcyjne dla państw zachodnich, gwarantując za ustępstwa zachodnie jedynie swobodę komunikacji i łączności, które już wcześniej Zachód okazał się zdecydowany skutecznie bronić. Autorzy notatki podkreślali, że po zmianach podtrzymane zostanie stanowisko sowieckie: osłabiałyby one pozycję państw zachodnich w Berlinie Zachodnim (status okupacyjny), wprowadzałyby NRD do systemu kontroli zobowiązań wobec Berlina Zachodniego, a ZSRS byłby nie tylko gwarantem, ale i kontrolerem przestrzegania zobowiązań politycznych (zakaz dywersji i propagandy). Doświadczeni dyplomaci polscy wiedzieli na pewno, że dostrzegą to natychmiast politycy zachodni ${ }^{10}$.

Powyższa ocena skłania do wniosku, że także dla Lachsa i Łobodycza zasadnicze znaczenie miało oddziaływanie na międzynarodową opinię publiczną. $\mathrm{W}$ innej notatce, niepodpisanej i pochodzącej $\mathrm{z}$ tego samego okresu, stwierdzano: „W naszym interesie leży podkreślanie naszej gotowości do współdziałania w podejmowaniu kroków, które zapobiegałyby ryzykom związanym z zachodnio-niemieckimi zbrojeniami atomowymi, z umocnieniem pozycji politycznej NRF wobec państw zachodnich i możliwością wykorzystania przez NRF tej sytuacji. Możemy przy tym jednocześnie wykorzystać i pogłębić sprzeczności, zwłaszcza w krajach skandynawskich i w Anglii na tle sprawy zbrojeń atomowych w NRF. Zasadnicze znaczenie ma tu oddziaływanie na opinię publiczną w tych krajach przy maksymalnym wykorzystaniu również możliwości

9 Ibidem, s. 59-60.

${ }^{10}$ Niepodpisana notatka [1961], AMSZ 26/1/10, s. 52-61. Tak silne wyeksponowanie kwestii Berlina Zachodniego oznaczało istotną zmianę. Łobodycz pisał: „Polski plan był $\mathrm{w}$ istocie rzeczy powiązany $\mathrm{z}$ problemem rozbrojenia jako częściowe rozwiązanie $\mathrm{w}$ tej dziedzinie, oraz z problemem zahamowania zbrojeń zachodnioniemieckich. Podejmując koncepcję Undena, moglibyśmy powiązać dezatomizację z aktualnym, ostrym problemem politycznym, którego uregulowanie leży również w interesie Zachodu. Problem taki stanowi uregulowanie sprawy Berlina Zachodniego", Notatka Łobodycza z 30 października 1961, AMSZ 26/1/10, s. 235-236. Pisał to jesienią 1961 roku, ale takie wykorzystanie propozycji rozbrojeniowych widoczne jest w opracowaniach MSZ od początku roku. 
wpływania na pozycję niektórych kół rządowych w tych krajach"11. Opinia publiczna, także w USA, rzeczywiście była coraz bardziej zaniepokojona zagrożeniami związanymi z próbami jądrowymi przeprowadzanymi w atmosferze. Nastrój ten nasilił się jeszcze w latach 1962-1963.

Nikita Chruszczow zaproponował, by Komitet Rozbrojeniowy rozpoczął 14 marca 1962 roku obrady na najwyższym szczeblu, przy udziale szefów państw lub rządów. Do Polski nadszedł jeszcze list I sekretarza Komunistycznej Partii Czechosłowacji, Antonina Novotnego, deklarującego poparcie dla inicjatywy Chruszczowa: „Problem rozbrojenia dojrzał do natychmiastowego rozwiązania"12. Wobec oporu państw zachodnich Moskwa zgodziła się na otwarcie na szczeblu ministrów spraw zagranicznych. Minister Rapacki ustalił podczas spotkania z sowieckim dyplomatą w Warszawie, że spotkanie delegacji Polski i ZSRS odbędzie się „po drodze w Warszawie”, aby ustalić ostatnie szczegóły ${ }^{13}$.

Spotkanie w Genewie pokazało niemożność ustalenia wspólnego planu działań. Zbyt silne były rozbieżności w sprawie likwidacji broni jądrowej, baz wojskowych, zbrojeń konwencjonalnych i ich redukcji, mechanizmów kontroli, zasad przechodzenia do kolejnych etapów rozbrojenia, środków częściowych oraz zaprzestania prób z bronią jądrową. Dyplomacja polska wykorzystała spotkanie do zaprezentowania, 28 marca 1962 roku, trzeciej wersji planu Rapackiego. Projekt przewidywał rozszerzenie zasięgu terytorialnego, realizację planu w dwóch etapach oraz częściową redukcję zbrojeń konwencjonalnych. Zastrzeżenia państw zachodnich pozostały niezmienione: naruszenie równowagi sił, brak skutecznych mechanizmów kontrolnych, pozbawienie RFN prawa obrony terytorialnej i utrudnianie zjednoczenia Niemiec ${ }^{14}$. W polskiej ocenie plan spełnił swoje zadanie, podtrzymując zainteresowanie strefami bezatomowymi, zmuszając państwa zachodnie do defensywy i wskazując na niebezpieczeństwa zbrojeń jądrowych RFN $^{15}$.

\footnotetext{
${ }^{11}$ Niepodpisana notatka [1961], AMSZ 26/1/10, s. 25-34. Teczka zawiera też liczne materiały, dotyczące kontaktów z organizacjami i działaczami pacyfistycznymi.

${ }^{12}$ List Antonina Novotnego do PZPR z 16 lutego 1962, AMSZ 26/3/21, s. 33-35.

${ }^{13}$ Notatka Rapackiego z rozmowy, 3 marca 1962, AMSZ 26/3/21, s. 115-118.

${ }^{14}$ T. Łoś-Nowak: Problem rozbrojenia w polskiej polityce zagranicznej, Warszawa 1985,

${ }^{15}$ Notatka analityczno-sprawozdawcza z dotychczasowych prac Konferencji Rozbrojeniowej w Genewie Naszkowskiego dla Gomułki z 22 czerwca 1962 (268/Naszk./62), AMSZ 1/77.
} s. 84 . 
Jesienią 1962 roku ZSRS zmodyfikował swój plan rozbrojeniowy. Nieznacznie wydłużono go $-\mathrm{z}$ czterech do pięciu lat. Przewidziano pozostawienie $\mathrm{w}$ pierwszym okresie pewnej liczby rakiet dwóm wielkim mocarstwom, wychodząc naprzeciw postulatom amerykańskim. Nie przewidziano istotnych zmian w zakresie mechanizmów kontroli. Uwzględniono amerykańskie propozycje dotyczące redukcji broni konwencjonalnej i określenia górnego pułapu sił zbrojnych ZSRS i USA ${ }^{16}$.

Rozbrojenie pozostawało przedmiotem obrad na forum ONZ, a kraje bloku wschodniego dokładnie koordynowały swoje działania. Najaktywniejsza rola, po ZSRS, przypadła Polsce i Czechosłowacji: „Delegacja czeska $\mathrm{w}$ swych wystąpieniach zajęła się szerzej problemem baz na obcych terytoriach i problemem tzw. ukrytych broni, wiążąc obydwa te zagadnienia z projektem Gromyki. Nasze przemówienia położyły akcent na problem zapewnienia państwom w procesie rozbrojenia bezpieczeństwa i pokoju. Delegacje Bułgarii i Rumunii skoncentrowały się w dotychczasowej dyskusji na krytyce wykrętnej taktyki delegacji zachodnich wobec planu Gromyki"17.

Po tym, jak Polska potępiła epizod w Zatoce Świń w 1961 i „siły imperialistyczne" w USA, polska inicjatywa w Genewie nie miała żadnych szans na poważne potraktowanie. Postrzegana była jako sowiecki manewr. Odrzucenie nowej wersji Planu Rapackeigo było jednak wynikiem bardziej zasadniczej niezgodności. W ocenie MSZ Stany Zjednoczone dążyły do poszerzenia obszaru stacjonowania broni atomowej, aczkolwiek pozostającej pod nadzorem amerykańskim. Dotyczyło to także NATO jako (jak to określano) czwartego mocarstwa atomowego. Uważano, że John F. Kennedy jest życzliwiej nastawiony do państw neutralnych, a także chce wzmocnić NATO, ale bez udostępniania tajemnic atomowych Francji i broni atomowej RFN. W końcu 1961 roku Stany Zjednoczone zdystansowały się od planów strefy bezatomowej w Europie Środkowej ${ }^{18}$. Za niechętne planom takiej strefy uważano Włochy, Wielką Brytanię, Holandię i Francję. Włochy kontynuowały swoje nie-

\footnotetext{
${ }^{16}$ Notatka dla Naszkowskiego z 26 października 1962, AMSZ 26/3/22, s. 96-102. Druga faza Konferencji Rozbrojeniowej trwała od 15 lipca do 8 września 1962. Także ona nie przyniosła istotnych wyników, wobec niezmiennych rozbieżności koncepcji.

${ }^{17}$ Notatka, styczeń 1963, AMSZ 26/3/23, s. 120-132, cytat s. 126.

${ }^{18}$ Notatka z 30 października 1961, AMSZ 26/1/10, s. 226-234.
} 
chętne nastawienie do Planu Rapackiego, uznając go za osłabiający Europę przez utrwalanie podziału Niemiec ${ }^{19}$. Słabło poparcie dla Planu w krajach skandynawskich, najsilniejsze zaś było ze strony państw niezaangażowanych Afryki i Azji, w połączeniu z przedłożeniem podobnych projektów np. odnośnie do Afryki ${ }^{20}$.

Nadal prowadzono prace nad projektem Paktu o nieagresji między państwami Układu Warszawskiego i NATO. ZSRS przedłożyło taki projekt 20 lutego 1963 roku i był on z punktu widzenia Moskwy najważniejszy. Szczególnie istotna jest tutaj współczesna ocena, że Moskwa zakończyła $\mathrm{w}$ ten sposób przede wszystkim propagandowe traktowanie problemu rozbrojenia ${ }^{21}$, a w nim przecież szczególną rolę odgrywał Plan Rapackiego. W MSZ oczekiwano w drugiej połowie 1962 roku na polepszenie stosunków Wschód-Zachód, mając także świadomość, że nie będą to szybkie zmiany.

Wobec nieosiągnięcia uznania granicy polsko-niemieckiej i normalizacji stosunków z RFN dyplomacja polska nadal wykorzystywała Plan Rapackiego. W ocenie MSZ, „po zawarciu Układu Moskiewskiego, który zachęcił do kontynuowania linii częściowych rozwiązań odprężeniowych powstały bardziej sprzyjające warunki do ożywienia dyskusji nad polską propozycją w sprawie utworzenia strefy bezatomowej i ograniczonych zbrojeń w Europie Środkowej". Strefy bezatomowe cieszyły się poparciem państw afrykańskich, Ameryki Łacińskiej, a także niektórych zachodnich. Nie miały jednak szerszego poparcia, gdy dotyczyły ważnych obszarów ${ }^{22}$. Lachs widział $\mathrm{w}$ tym szansę podtrzymania dyskusji o strefach, w sytuacji gdy polska propozycja nie miała szans na realizację i nie było sensu jej ponawiać. Stąd za bardziej celową uważał ogólną rezolucję w sprawie stref bezatomowych, która mogłaby stanowić

${ }^{19}$ G. Bernatowicz: Stosunki polsko-wotoskie 1944-1989, Warszawa 1990, s. 77. O stanowisku brytyjskim J. Tebinka, op. cit., s. 181.

${ }^{20}$ Niepodpisana notatka [1961], AMSZ 26/1/10, s. 7-16.

${ }^{21}$ Por. taką ocenę zmiany polityki sowieckiej V.B. Zubok: Unwrapping the Enigma: What Was Behind the Soviet Challenge in the 1960s?, w: D.B. Kunz, The Diplomacy of the Crucial Decade: American Foreign Relations during the 1960s, New York 1994, s. 149-182, tu s. 162.

${ }^{22}$ Anonimowe opracowanie z sierpnia 1963, AMSZ 26/4/37, s. 3-4. Tekst w AMSZ 26/5/45, s. 2-4, oraz w M. Tomala (oprac.): Na drodze do wspótpracy i przyjaźni: Warszawa - Bonn 1945-1995. Wybór dokumentów i materiałów, Warszawa 1996, s. 48-49. 
punkt wyjściowy do dalszych konkretnych planów ${ }^{23}$. Zastrzeżenia Lachsa nie zostały uwzględnione, gdyż Rapacki podzielał opinię, że Układ Moskiewski polepszył atmosferę dla starań o realizację częściowych rozwiązań w zakresie odprężenia i rozbrojenia. Tym samym „wzrosły również szanse na aktywizację polskiej inicjatywy w sprawie utworzenia strefy bezatomowej w Środkowej Europie". Rapacki realistycznie uznał, że poparcie dla planu nie wzrosło istotnie, natomiast zastrzeżenia dotyczą głównie części drugiej planu, czyli dezatomizacji. Szerokie zainteresowanie budzi natomiast pomysł zamrożenia zbrojeń nuklearnych. Dlatego wskazane będzie wysunięcie etapu pierwszego jako samodzielnego celu. Postawi to w niewygodnej sytuacji RFN oraz pogłębi sprzeczności w ruchu socjaldemokratycznym w Europie i RFN ${ }^{24}$.

\section{Plan Gomułki}

Zgodnie z oceną Rapackiego o celowości kontynuowania inicjatywy, w dniu 28 grudnia 1963 roku zgłoszony został kolejny plan, tzw. Plan Gomułki, przekazany następnie w formie memorandum z 29 lutego 1964 państwom zachodnim. Plan Gomułki przewidywał zamrożenie zbrojeń jądrowych i termojądrowych na terytorium Polski, Czechosłowacji, NRD i RFN „zobowiązanie nieprodukowania, nieprowadzenia względnie niesprowadzania, nieprzekazywania innym stronom na tym obszarze względnie nieprzyjmowania od innych stron na tym obszarze wyżej wymienionych broni jądrowych i termojądrowych". Uwzględniono możliwość przystąpienia do niego innych państw, rozbudowano mechanizmy kontroli i weryfikacji ${ }^{25}$.

Plan Gomułki miał być bardziej pragmatyczny. Przesunięcie punktu ciężkości z likwidacji broni atomowej na jej zamrożenie miało osłabić zachodnie zarzuty o dążeniu do naruszenia równowagi sił. Plan nie zo-

${ }^{23}$ Notatka Lachsa dotycząca projektu rezolucji w sprawie stref bezatomowych, które Delegacja Polska zamierza wnieść na XVIII Sesji ZO ONZ z 30 sierpnia 1963 (382(NL/63), AMSZ 1/77.

${ }^{24}$ Notatka Rapackiego „Nowe elementy taktyki w walce o strefę bezatomową w Europie Środkowej" z 17 grudnia 1963 (550/Rap./63), AMSZ 1/77.

${ }^{25}$ Łoś-Nowak, Problem rozbrojenia..., s. 93. 
stał przyjęty, gdyż dotyczył kluczowej sfery zbrojeń w najważniejszym w zimnowojennym konflikcie obszarze Europy. Był w pewnym zakresie samodzielną inicjatywą Gomułki, niezadowolonego z sowieckich planów w sprawie nieproliferacji broni jądrowej. Gomułka swoją koncepcją utrudnił plany Chruszczowa, a zarazem zmusił go do zadeklarowania poparcia dla planu polskiego sojusznika ${ }^{26}$.

W tym czasie Manfred Lachs, doradca ministra ds. rozbrojenia, oceniał: „Rozmowy rozbrojeniowe znajdują się nadal w impasie, którego przyczyną jest brak uzgodnienia stanowisk ZSRR i USA w odniesieniu do zasadniczych problemów rozbrojenia. [...] Wydaje się, że jeżeli do dyskusji nad propozycją radziecką nie zostaną wniesione nowe konkretne elementy, impas w rokowaniach nie zmniejszy się, a biorąc pod uwagę znaczenie jakie problem ten ma dla rozwiązania całego zagadnienia powszechnego i całkowitego rozbrojenia, może to uniemożliwić roboczą dyskusję również nad innymi sprawami"27. Tym samym Plan Gomułki postrzegany był w MSZ jako jeden z elementów „środków częściowych", na które chciano położyć większy nacisk. Przewidywano, że także w 1964 roku środki częściowe pozostaną głównym obszarem zainteresowania Komitetu 18. ${ }^{28}$.

\footnotetext{
${ }^{26}$ Błędna jest ocena o niezależności polskiej inicjatywy (tak A. Skrzypek: Mechanizmy autonomii. Stosunki polsko-radzieckie 1956-1965, Pułtusk 2005, s. 271-275). W listopadzie 1963 roku Plan Gomułki konsultowany był w rozmowie Rapacki-Andriej Gromyko, z NRD w lutym 1964 roku, z Czechosłowacją w grudniu 1963 roku oraz szerzej podczas konsultacji przed Genewą. ZSRS, CSRS i NRD otrzymały tekst na dziesięć dni przed jego oficjalnym wręczeniem (por. Tezy Min. Rapackiego, data wpływu 26 lutego 1965, AMSZ 1/77). Nie powinniśmy zatem mówić o zaskoczeniu, a o zdolności Gomułki do przeforsowania inicjatywy, wymuszającej pewną korektę sowieckiej polityki zagranicznej.

${ }^{27}$ Notatka Lachsa dotycząca zbliżającej się Konferencji Komitetu 18 państw w Genewie, AMSZ 26/9/70, s. 2-5. Lachs uważał, że podczas konsultacji w Moskwie przed konferencją należy starać się o ograniczenie liczby tematów rokowań, aby (1) umożliwić ustalenie porządku obrad, co dotychczas było zawsze problemem, (2) umożliwić roboczą dyskusję nad nimi. Lachs uważał ponadto za ważną część obrad program tzw. środków częściowych, czyli paktu o nieagresji, stref bezatomowych i być może posterunków kontrolnych „w powiązaniu z podjęciem pewnych środków rozbrojeniowych na obszarze obu państw niemieckich". Konsultacje miały się odbyć 8 stycznia.

${ }^{28}$ Ocenę o niemożności opracowania całościowego układu o powszechnym i całkowitym rozbrojeniu oraz rosnącym w związku z tym znaczeniu częściowych środków rozbrojeniowych powtórzył Naszkowski w specjalnej notatce dla Gomułki z 18 stycznia 1964 roku, AMSZ 26/9/70, s. 34-42. Ze strony zachodniej obejmowały one: notyfikacje
} 
W sowieckiej ocenie, zawartej $\mathrm{w}$ aide-mémoire MID [Ministierstwa Innostrannych Dieł] z 12 marca 1964 roku, widziano w polskiej inicjatywie przede wszystkim ograniczenie aspiracji RFN do broni jądrowej: „Pozytywne znaczenie porozumienia o zamrożeniu zbrojeń jądrowych w Środkowej Europie - jeśliby takie porozumienie zostało zawarte - widzimy przede wszystkim $\mathrm{w}$ tym, że powinno ono zamknąć drogę odwetowcom zachodnioniemieckim do broni jądrowej. $W$ tym kierunku - jak rozumiemy - zmierzają postanowienia Memorandum Rządu PRL przewidujące, że uczestnicy porozumienia przyjmą zobowiązania nieprodukowania, niewprowadzania i niesprowadzania, nieprzekazywania drugim państwom w regionie Środkowej Europy i nieprzyjmowania od drugich państw w tym rejonie broni jądrowej". Polska propozycja miała uniemożliwić powstanie MLF, natomiast $\mathrm{w}$ sprawie mechanizmów kontroli zbrojeń decydujące było stanowisko Moskwy ${ }^{29}$.

Perspektywa dyplomacji polskiej była trochę inna. W odpowiedzi na sowieckie aide-mémoire z 12 marca MSZ przekazał ambasadorowi Awierkijowi Aristowowi 27 marca aide-mémoire, w którym szerzej wyjaśniał polskie cele. Zablokowanie zbrojeń jądrowych stanowiło w nich przede wszystkim punkt wyjścia do ofensywnych działań politycznych:

„Najistotniejsze jednak są efekty polityczne, jakie wywołałaby realizacja naszego planu. Nie ulega bowiem wątpliwości, że zamrożenie zbrojeń jądrowych Środkowej Europie spotęgowałoby opory, jakie występują dzisiaj w łonie państw zachodnich wobec wielostronnych sił jądrowych NATO. Powstałaby nowa sytuacja polityczna, wyrażająca się w poważnym odprężeniu i działająca na rzecz zasadniczej rewizji zachodnich koncepcji polityczno-strategicznych, której wyrazem są plany utworzenia wielostronnych sił jądrowych. W tej nowej atmosferze ubieganie się NRF o utworzenie tych sił musiałoby być przyjęte przez światową opinię publiczną jako nowy dowód złej woli NRF i świadectwo przeciwstawienia się wszelkim krokom odprężeniowym.

Jeżeli zaś - co jest najbardziej prawdopodobne - NRF odrzuci naszą propozycję, będzie to dodatkowym dowodem, że nie chce się ona wy-

o ruchu wojsk, wymianę misji wojskowych, ustanowienie bezpośredniej łączności między Moskwą i Waszyngtonem oraz posterunków kontrolnych. Z wszystkich propozycji zrealizowane zostało jedynie ustanowienie bezpośredniej łączności.

${ }_{29}$ Tłumaczenie aide-mémoire w AMSZ 26/9/70, s. 20-21. 
rzec samodzielnych zbrojeń nuklearnych i że swój udział w wielostronnych siłach jądrowych traktuje jedynie jako etap samodzielnego władania bronią jąd rową.

W ten sposób propozycja polska przyczyni się do realizacji jednego z głównych celów polityki naszego obozu - izolowania NRF jako przeciwnika odprężenia i rozbrojenia, a zarazem odegra pozytywną rolę $\mathrm{w}$ walce $\mathrm{z}$ wielostronnymi siłami jądrowymi" ${ }^{30}$.

Na naradzie w dniu 17 kwietnia 1964 roku w MSZ Rapacki powtórzył: „Główny kierunek naszej akcji - to dalsze izolowanie NRF”31.

Istniały trudności w uzgodnieniu stanowiska Warszawy z Berlinem Wschodnim. Nie doszły do skutku planowane w grudniu 1963 roku konsultacje Rapackiego w Berlinie, a NRD wystąpiło z inicjatywą porozumienia między NRD a RFN w sprawie rezygnacji z broni jądrowych przez oba państwa niemieckie. Strona polska nie była o tej inicjatywie informowana ${ }^{32}$. Władze NRD uważały, że Plan Gomułki nie był z nimi w wystarczającym zakresie konsultowany. Proponowały zwołanie 19 marca 1964 posiedzenia Doradczego Komitetu Politycznego (DKP) Układu Warszawskiego w Moskwie, jednakże Warszawa uznała ponowne (po konsultacjach 8-9 stycznia w Moskwie) podejmowanie dyskusji na tak wysokim szczeblu za zbędne. Nie chciała dłużej odwlekać przygotowania memorandum ${ }^{33}$. Wreszcie, godząc się, zaproponowała kwiecień, ponownie podkreślając, że chodzi o zamanifestowanie poparcia dla polskich inicjatyw (czyli nie o dyskusję nad nimi) ${ }^{34}$.

Podczas konsultacji Polska-NRD dyplomaci wschodnioniemieccy starali się załagodzić wcześniejsze napięcia, skoro według Rapackiego chcieli "Załagodzić wrażenie dotychczasowego zachowania się NRD w sprawie naszej inicjatywy". Początkowo NRD uważało za niewystarczające ograniczenie, by broń jądrowa nie mogłaby być wprawdzie przechowywana na terenie RFN, ale RFN mógłby mieć prawo współ-

\footnotetext{
${ }^{30}$ Tekst polskiego aide-mémoire w AMSZ 26/9/70, s. 197-198.

${ }^{31}$ Notatka z 24 kwietnia 1964, AMSZ 26/9/72, s. 84-88.

32 Projekt pisma do Waltera Ulbrichta z 6 lutego 1964, AMSZ 26/9/70, s. 87-89.

${ }^{33}$ Por. pisma w AMSZ 26/9/70, s. 51-53, 114-116 (87-89 projekt). W projekcie pisma do Chruszczowa przyjęło to formę zgody na posiedzenie DKP, jeżeli ma służyć ponownemu poparciu inicjatyw podejmowanych przez ZSRS i inne kraje bloku (s. 90).

34 Por. pismo do Chruszczowa (kopia) z 8 lutego 1964, AMSZ 26/9/70, s. 109.
} 
decydowania o jej użyciu oraz produkowania jej poza swoim obszarem. Uważała ponadto, że wyłączenie MLF bezpośrednio z Planu Gomułki stworzy wrażenia akceptowania ich przez Polskę. Ustalono wspólne działanie propagandowe przeciw MFL, ale bez istotnego związku ze zgłoszonym planem. Minister spraw zagranicznych NRD, Lothar Bolz, zgodził się, że bardziej bezpośrednie wprowadzenie tej problematyki do Planu Gomułki umożliwiłoby łatwe jego odrzucenie ${ }^{35}$.

Plan Gomułki był sprzeczny z polityką NATO, które w maju 1963 roku postanowiło utworzyć międzysojusznicze siły nuklearne, wycofując się rok później z tych planów, ale doceniając znaczenie broni atomowej. Brakowało poparcia Francji, prowadzącej badania nad bronią atomową i nastawionej na współpracę polityczną z RFN. Paryż uważał, że każdy taki plan prowadziłby do neutralizacji Niemiec i burzyłby równowagę militarną w Europie ${ }^{36}$. Wspólny dla większości zachodnich stanowisk był argument o burzeniu równowagi sił. Łagodniejsza była reakcja państw skandynawskich, aczkolwiek Józef Winiewicz pozostawał sceptyczny: „Jeżeli w dalszym rozwoju - Skandynawowie nawet nie poprą naszych propozycji, to nawiązany z nimi kontakt spowoduje wyrażenie ew. zastrzeżeń $\mathrm{w}$ znacznie bardziej umiarkowanej formie. W każdym razie pozostanie nowy zadatek na dalszy dialog polityczny z nimi a wszyscy deklarowali zamiar szerokiego rozwijania współpracy dwustronnej" ${ }^{\prime 37}$. Łagodniej potraktowała polskie propozycje Kanada i Belgia, ostrzej RFN i Kanada. Negatywne stanowisko zajęła Wielka Brytania, aczkolwiek starała się to zrobić nie urażając Polski.

Także Wyszyngton, po słowach docenienia polskich starań o rozbrojenie, uznał projekt za inadequate, bo nieobejmujący zachodniej części ZSRS oraz pozostawiający nierozwiązane problemy polityczne $\mathrm{w}$ tym regionie Europy. Stany Zjednoczone preferowały propozycje Lyndona B. Johnso-

${ }^{35}$ Notatka Rapackiego z 29 lutego 1964, AMSZ 26/5/43, s. 29-31: „W dłuższym wywodzie Tow. Rapacki podkreślił pryncypialne, negatywne stanowisko Polski wobec MLF i wyjaśnił, że wprowadzenie poprawki NRD ułatwiłoby odrzucenie propozycji polskiej przez rządy i koła jej niechętne, a utrudniłoby postawę tych kół, które interesują się propozycją polską m.in. jako elementem politycznym w walce z MLF". Notatka z rozmowy z ministrem spraw zagranicznych NRD Bolzem w dniu 27 lutego 1964, 2 marca 1964, AMSZ 26/9/70, s. 158.

${ }^{36}$ M. Pasztor: op. cit., s. 161.

${ }^{37}$ Notatka Winiewicza z 29 stycznia 1964, AMSZ 26/5/45, s. 15-21. 
na: „weryfikowane zamrożenie” wehikułów nuklearnych, nierozprzestrzenianie zbrojeń jądrowych. Ponieważ jednak była w nich mowa o nierozprzestrzenianiu „niezależnej zdolności jądrowej”, dopuszczały więc MLF. Ogółem nota amerykańska sformułowana była tak, by nie zaogniać napięć z Warszawą i zostawić przestrzeń do dalszej dyskusji. Wiceminister Józef Winiewicz odpowiedział ambasadorowi Johnowi M. Cabotowi, że rozumie odmowę jako tendencję dalszego wzmacniania zbrojeń jądrowych w RFN. Odrzucił także określenie „zona sowiecka” dla NRD ${ }^{38}$.

Władzom RFN memorandum przekazano za pośrednictwem ambasadora w Bonn w Indiach, Georga Ferdinanda Duckwitza. Ocenione to zostało przez stronę zachodnioniemiecką negatywnie, gdyż plan nie przynosił żadnego postępu w kwestii niemieckiej ${ }^{39}$. Konrad Adenauer od drugiej połowy lat pięćdziesiątych zaczął rozumieć, czym jest broń atomowa i co oznacza jej użycie na terenie Niemiec. Rozumiał także, że zapewne nieunikniona będzie rezygnacja z broni atomowej przez RFN. Było dość oczywiste, że RFN nie może prowadzić takiej polityki jak Francja, nie ma możliwości „opcji narodowej” ${ }^{40}$. Rosnącemu przekonaniu Adenauera, że możliwa jest pokojowa koegzystencja i jest ona także $\mathrm{w}$ interesie ZSRS, towarzyszył sprzeciw wobec takich pomysłów, jak strefy bezpieczeństwa, które - jak uważał - nie chronią przed niczym, nie uchronią także przed atakiem jądrowym ${ }^{41}$.

${ }^{38}$ O stanowisku USA notatka Winiewicza z 29 kwietnia 1964, MSZ 26/8/62, s. 31-32.

${ }^{39}$ D. Bingen: Polityka Republiki Bońskiej wobec Polski. Od Adenauera do Kohla 1949-1991, Kraków 1997, s. 88. Niejasny sondaż Schwarzensteina, że RFN mogłoby przedyskutować plan Gomułki, gdyby formuła uszanowania ich stanowiska w sprawie zjednoczenia Niemiec, notatka Winiewicza z 15 września 1964, AMSZ 26/5/43, a. 182-183.

${ }^{40}$ Wydaje się, że broń jądrowa nie stanowiła początkowo specjalnego obszaru zainteresowania Adenauera. Odrzucenie idei strefy bezatomowej wynikało m.in. z takich przesłanek, jak przekonanie, że Moskwa potrzebowałaby potencjału ekonomicznego Niemców, a nie Niemiec zniszczonych wojną nuklearna, oraz że mocarstwa atomowe trzymają się w szachu i nie użyją tej broni. Messmer przypominała następujący opis oceny przez Adenauera broni atomowej „Nuclear weapons are not immoral. A gun in the hand of a murderer is immoral. Effective defence weapons are not immoral. A totalitarian state that considers the use of force a permissible principle when its goal can be achieved with little risk is immoral". Znaczenie broni atomowej zrozumiał w pełni prawdopodobnie od drugiej połowy lat sześćdziesiątych. (por. A. Messmer: Konrad Adenauer: Defence Diplomat on the Backstage, w: J.L. Gaddis i in. (red.): Cold War Statesmen Confront the Bomb: Nuclear Diplomacy since 1945, Oxford 1999, s. 236-259, tu s. 238-239, 249 i n.

${ }^{41}$ Ibidem, s. 257. 
Zgodnie z oczekiwaniami reakcje państw NATO były w zasadzie negatywne, utrzymane $w$ różnym tonie, ale zgodne ze wspólnym stanowiskiem wypracowanym w kwietniu 1964 roku w Komitecie Politycznym NATO. MSZ przygotował zestawienie zarzutów zawartych w odpowiedziach państw zachodnich:

Zarzuty polityczne:

1. Działania w zakresie bezpieczeństwa i kontroli ubrojeń w Europie Środkowej nie mogą być traktowane oddzielnie od problemów politycznych $\mathrm{w}$ tym regionie.

2. Jakiekolwiek porozumienie $\mathrm{w}$ zakresie bezpieczeństwa nie może opierać się na podziale Niemiec.

3. Plan polski dotyczy tylko jednego członka NATO, a tym samym dyskryminuje go wobec innych państw NATO.

Zarzuty wojskowo-strategiczne:

1. Nieobjęcie zamrożeniem zbrojeń części ZSRS, co naruszałoby równowagę sił.

2. Główne zagrożenie dla Europy Zachodniej stanowi broń na terenie ZSRS.

3. Zakaz przekazywania broni byłby sprzeczny ze zobowiązaniami sojuszniczymi NATO.

4. Nieobjęcie zamrożeniem ani kontrolą zbrojeń konwencjonalnych w strefie bezatomowej naruszałoby równowagę sił.

5. Na wschodzie istnieją większe możliwości przeniesienia zbrojeń niż na zachodzie Europy.

Zarzuty techniczne:

1. Niewystarczająca jest proponowana kontrola.

2. System inspekcji byłby bardzo rozległy, uciążliwy i kosztowny.

3. Nie przewiduje się kontroli nad przekazywaniem broni jądrowej wewnątrz strefy.

4. Kontrola nad zakazem produkcji materiałów roszczepialnych dla celów wojskowych wymaga ujawnienia odpowiednich urządzeń do ich produkcji. Polska nie jest w stanie tego zagwarantować.

5. Różnice w liczbie głowic jądrowych spowodowałby nierównowagę kontroli na niekorzyść Zachodu. 
6. Włączanie kolejnych państw do strefy ma znaczenie tylko wtedy, gdy posiadają one broń atomową lub urządzenia do jej produkcji.

7. Zamrożeniu zbrojeń musiałoby towarzyszyć utworzenie posterunków obserwacyjnych.

8. Propozycje prezydenta Johnsona są lepszym punktem wyjścia do rozwiązania problemu rozbrojenia ${ }^{42}$.

Wobec tak jednoznacznego stanowiska minister Rapacki wypracował koncepcję eksponowania - ze względów propagandowych - tylko wymiany not z RFN, połączonego z podkreślaniem odmienności polityki RFN i państw zachodnich. Kontynuowano próbę stworzenia atmosfery izolacji RFN, przekonania przede wszystkim polskiej opinii publicznej, że RFN ponosi główną odpowiedzialność za odrzucenie polskiej inicjatywy. Należało odrzucić wszelkie sugestie objęcia zamrożeniem części ZSRS, starać się eksponować różnice między polityką poszczególnych państw zachodnich, zwłaszcza między RFN a pozostałymi. Minister zalecał ponadto, aby podtrzymywać rozmowy z pozostałymi państwami. Publiczna reakcja na ich odpowiedzi będzie możliwa „W momencie ujawnienia się największych rozbieżności między państwami NATO, kiedy umocni się przekonanie, że główna odpowiedzialność za odrzucenie inicjatywy spada na $\mathrm{NRF}^{\prime 43}$.

\section{Abstract \\ Polish diplomatic attempts at reviving the Rapacki Plan in the early 60s}

The article describes the political context of the revival, in early $60 \mathrm{~s}$, of the Rapacki Plan. The tradition in Polish historiography holds its main objective to have been a disarmament. Ministry of Foreign Affairs documents, which are currently available make a much more balanced and differentiated approach to its appraisal possible. The article takes into account both a certain autonomy present in the Polish initiative and its dependence on Soviet policy. At the ministry in Warsaw, they were aware that a disarmament initiative as such had meagre chances of being

\footnotetext{
${ }^{42}$ „Wykaz zarzutów względnie sugestii zmian zawartych w odpowiedziach Kanady, USA, NRF, WBrytanii, Belgii, Holandii, Włoch i Luksemburga na memorandum Polski", AMSZ 26/5/45, s. 22-24.

${ }^{43}$ Notatka Rapackiego z 19 maja 1964, AMSZ 26/5/45, s. 25-29 i z 18 maja, ibidem 26/9/72, s. 120-123.
} 
implemented; nevertheless, it could provide an effective tool for the carrying out of foreign policy. What is particularly interesting is the use of the Rapacki Plan as an instrument aimed at restricting the political influences of the Federal Republic of Germany in the 60s, which can be seen in the documents. Minister Rapacki had elaborated upon an idea for focussing attention on West German opposition to the Polish proposals, for propaganda reasons. These efforts aimed at creating an atmosphere of isolation around the FRG and most of all, at persuading the Polish public opinion that it was the FRG which was most responsible for the rejection of the Polish initiative. 